\title{
Yield and yield attributes of lowland rice as affected by weed control methods in Sudan savanna zone of Kebbi State Nigeria
}

\author{
Folorunsho E., Muhammad A., Na-Allah M. S. ${ }^{*}$, Bubuche T. S. and Tanimu M. U. \\ Department of Crop of Science Kebbi State University of Science and Technology, Aliero, Nigeria. \\ *Corresponding author. Email: pyaks2010@gmail.com
}

Copyright (@) 2021 Folorunsho et al. This article remains permanently open access under the terms of the Creative Commons Attribution License 4.0, which permits unrestricted use, distribution, and reproduction in any medium, provided the original work is properly cited.

Received 26th February, 2021; Accepted 9th April, 2021

\begin{abstract}
Field experiment was conducted during 2019 rainy season at the Experimental/Seed Multiplication Farm of National Cereals Research Institute (NCRI), Rice Research sub-station, Gwadangaji, Birnin Kebbi, Kebbi State (latitude $12^{\circ} 11^{\prime}$; longitude $\left.12^{\circ} 4^{\prime}\right)$. The treatments consist of factorial combination of two level of Topstar spectrum 600 and $400 \mathrm{ml}$ ha $^{-1}$, two level of Cranstan spectrum 1250 and $800 \mathrm{ml} \mathrm{ha}^{-1}$; (pre-emergence and post-emergence herbicide), hoe weeding and a weedy check. The treatments were laid out in Randomized Complete Block Design (RCBD) and were replicated three times. Data were taken and subjected to analysis of variance (ANOVA) and means were separated using Duncan's Multiple Range Test (DMRT). Result obtained revealed that, Topstar at the rate of $600 \mathrm{ml} \mathrm{ha}^{-1}$ produced significantly higher number of productive tillers, panicle length, 1000 grain weight and grain yield. Topstar show highest weed control than all other treatments. Weed cover score and weed dry weight significantly responded to weed control treatments. The result also shows that weedy check consistently recorded the highest value for weed cover and weed dry weight which was followed by plot treated with Cranstan at $800 \mathrm{ml} \mathrm{ha}^{-1}$. Topstar at $600 \mathrm{ml} \mathrm{ha}^{-1}$ is found to be the best pre-emergence spectrum in weed management in rice field.
\end{abstract}

Keywords: Cranstan spectrum, rice, topstar spectrum, weedy check, weed cover.

\section{INTRODUCTION}

Rice belongs to grass family, Gramineae with genus Oryza and species sativa (Asian rice) or glaberrima (African rice). As a cereal, it is the most widely consumed staple food for a large part of the world's human population, especially in Asia (Anonymous, 2009). It is the Agricultural commodity with the third-highest worldwide production of 741.5 million tons after sugarcane (1.9 billion tones) and maize (1.0 billion tones) (FAOSTAT, 2017). Rice stands out as the major food crop for about a half of human race. The consumption of rice is growing faster than that of any other staple in Africa and the world at large, simply because it has become a convenient food for the growing world population. It is cultivated on almost $11 \%$ of the earth's cultivated land area and on a wide number of ecosystems (Abiwon et al., 2016). Rice is a weak competitor against weeds and the majority of African farmers have few options and resources available for effective weed control (Rodenburg and Johnson, 2009). Weeds are the most frequent and widespread biotic constraints to productivity throughout the rice environments of Africa (Balasubramanian et al., 2007). In sub-Saharan Africa (SSA), weeds are estimated to account for rice yield losses of at least 2.2 million tons (Mt) per year (Rodenburg and Johnson, 2009). Combined with costs of weed control, the financial losses easily surpass half the cost of current regional rice imports. If not controlled, weeds cause yield losses in the range of 28 to $74 \%$ in transplanted lowland rice, 28 to $89 \%$ in direct seeded lowland rice and 48 to $100 \%$ in upland rice (Rodenburg and Johnson, 2009). Weed control is carried out manually using hand hoe in the Nigerian Savanna. Manual hoe weeding is tedious and associated with serious drudgery. It is also costly and 
sometimes the labour is scarce or not available at the time of need. Considering the limitations of cultural methods of weed control, chemical weed control is an important alternative. Topstar and Cranstan have been demonstrated to give pre- and post-emergence control of several stubborn weeds in rice fields. They provide good control of annual and perennial grasses as well as many broadleaf weeds.

The study was aimed to evaluate and compare the efficacy of Topstar and Cranstan on management of weeds in lowland rice with the objective to determine the efficacy of Topstar on the growth and yield of lowland rice, efficacy of Cranstan (post-emergence) on the growth and yield of lowland and to find out the best herbicide and rates for high rice production

\section{MATERIALS AND METHODS}

The experiment was conducted at the rice research substation of National Cereals Research Institute Farm (NCRI), located at Gwadangaji (latitude $12^{\circ} 11^{\prime} \mathrm{N}$; longitude $12^{\circ} 4^{\prime} \mathrm{E}$ ) in Kebbi State during the 2019 wet season. The location lies within the Sudan Savanna ecological zone of Nigeria and hence exhibits the characteristic erratic and scanty rainfall that lasts for about five (5) months (May - September) and long dry period usually characterized by cool dry air during harmattan from November to February and hot dry air during hot season from March to May. The climate of the area is semi-arid with average rainfall of 550 to $650 \mathrm{~mm}$ per annum (NNN, 2012). Soil samples were randomly collected before land preparation using soil auger from a depth of 0 to $30 \mathrm{~cm}$ across the experimental sites prior to planting, bulked and composite soil was taken and analyzed for physical and chemical properties using standard procedure as described by Black (1965).

The experimental area was harrowed to a fine tilth. The land was then marked into plots of $4 \mathrm{~m} \times 4.5 \mathrm{~m}\left(18 \mathrm{~m}^{2}\right)$. Border spaces of $0.5 \mathrm{~m}$ and $1.5 \mathrm{~m}$ were left between plots and replicates, respectively. Treatment consisted of Topstar (oxadiargyl) pre-emergence herbicide at the rate 600 and $400 \mathrm{ml} \mathrm{ha}^{-1}$; Cranstan Spectrum (flurosypyrmeptyl and cyhalofop-butyl) post-emergence herbicide at 1250 and $800 \mathrm{ml} \mathrm{ha}^{-1}$; hoe weeding at 3 and 6 WAS; and weedy check as control. The experiment was laid out in Randomized Complete Block Design (RCBD) with three replicates. The gross plot size consisted of 6 rows each measured $4 \mathrm{~m}$ long and $4.5 \mathrm{~m}$ wide $\left(4 \mathrm{~m} \times 4.5 \mathrm{~m}=18 \mathrm{~m}^{2}\right)$. While the two inner ridges $4 \mathrm{~m} \times 1.5 \mathrm{~m}\left(6 \mathrm{~m}^{2}\right)$ constituted the net plot. The nursery beds of Faro 44 variety of $6 \mathrm{mx}$ $3 \mathrm{~m}\left(18 \mathrm{~m}^{2}\right)$ were made. The beds were fertilized with NPK 15:15:15 at $50 \mathrm{gm}^{-2}$. Rice seeds were sown by drilling at an inter-row spacing of $30 \mathrm{~cm}$. Seedlings were transplanted 3 weeks after planting when they were at 4 to 5 leaf stage. Gap filling was done within 7 to 10 days after transplanting (DAT) of rice seedlings to maintain the plant population. The first fertilizer dose was applied at the rate of $400 \mathrm{~kg} \mathrm{NPK}$ 15:15:15 per hectare as basal at 1 WAT. The second dose was applied at 4 WA, while Urea-46 was applied at 8 WAT. The pre-emergence herbicide (Topstar) was applied immediately after planting in the nursery while post-emergence herbicide (Cranstan) was applied at 3 weeks after sowing (WAS) on treatment basis. Hoe weeding was carried out at 3 and 6 WAT for the hoe weeded treatment only. Pests and diseases were controlled with appropriate recommended Phyto sanitary measures. Harvesting was done when 80 to $85 \%$ of the panicles turned yellow and grains in the lower part of the panicle are hard and not easily broken when squeezed between teeth. At that time the moisture content is assumed to be 18 to $25 \%$. The crop from the net plot area was harvested manually with the aid of sickle. Harvested plants were air-dried for 5 days. The grains were threshed and winnowed manually. Data were collected on the following weed and yield parameters weed cover score weed dry weight, panicle weight, 1000 grain weight and grain yield.

\section{Statistical analyses}

Data collected were subjected to analysis of variance (ANOVA). Means that are significantly different were separated using least significant difference (LSD). The relationships between the parameters were determined using correlation analysis.

\section{RESULTS}

Details of physico-chemical properties of soils at the experimental site is shown on Table 1. The results showed that the textural class of the soil was sandy loam, $\mathrm{pH}$ in water was slightly acidic (5.44), total nitrogen was moderate $\left(0.16 \mathrm{~g} \mathrm{~kg}^{-1}\right)$, available phosphorous was moderate $\left(17.31 \mathrm{mg} \mathrm{kg}^{-1}\right)$, organic carbon was also moderate (1.28) $\mathrm{g} \mathrm{kg}^{-1}$ and the exchangeable cations were, moderate Calcium $\left(3.99 \mathrm{cmol} \mathrm{kg}^{-1}\right)$, high Magnesium $\left(1.50 \mathrm{cmol} \mathrm{kg}^{-1}\right)$, medium Potassium $\left(0.22 \mathrm{cmol} \mathrm{kg}^{-1}\right)$, high Sodium $\left(0.56 \mathrm{cmol} \mathrm{kg}^{-1}\right)$ and low Cation Exchange Capacity $\left(1.30 \mathrm{cmol} \mathrm{kg}^{-1}\right)$.

Weed cover score significantly responded to weed control treatment at 8 and 12 WAT, the weedy check consistently recorded the highest value for weed cover which was followed by plots treated with Cranstan at 800 $\mathrm{ml} \mathrm{ha}^{-1}$. The remaining weed control measures recorded least value for weed cover score (Table 2). There was significant effect of weed control treatments on weed dry weight at all sampling periods. The highest weed dry weight was recorded in the weedy checks likewise all other weed control treatments recorded similar and least weed dry weight.

Hoe weeding at 4 and 8 WAT recorded highest panicle length which in turn were at par with plots treated with herbicides at all rates but significantly higher than the weedy check (Table 3). Plots treated with Topstar at 600 
Table 1. Analyzed at the soil science laboratory, Kebbi State University of Science and Technology, Aliero.

\begin{tabular}{lc}
\hline Soil characteristics & Results \\
\hline Particle size distribution $\left(\mathbf{g ~ k g}^{-1}\right)$ & \\
Sand & 540 \\
Silt & 360 \\
Clay & 100 \\
Textural class & Sandy loam \\
& \\
Chemical composition & \\
pH in water $(1: 2.5)$ & 5.44 \\
pH in $0.01 \mathrm{MCaCl}_{2}(1: 2.5)$ & 5.94 \\
Organic carbon $\left(\mathrm{g} \mathrm{kg}^{-1}\right)$ & 1.28 \\
Total nitrogen $\left(\mathrm{g} \mathrm{kg}^{-1}\right)$ & 0.16 \\
Available phosphorus (mg kg-1) & 17.31 \\
& \\
Exchangeable bases (cmol kg & -1 \\
Calcium $(\mathrm{Ca})$ & \\
Magnesium (Mg) & 3.99 \\
Potassium (K) & 1.50 \\
Sodium (Na) & 0.22 \\
Cation Exchange Capacity (C.E.C) & 0.56 \\
\hline
\end{tabular}

Table 2. Effect of weed control treatment on weed cover score and weed dry weight $\left(\mathrm{gm}^{2}\right)$ of rice at Birnin Kebbi during 2019 wet season.

\begin{tabular}{lcccccc}
\hline \multirow{2}{*}{ Weed control } & \multicolumn{3}{c}{ Weed cover score } & \multicolumn{3}{c}{ Weed dry weight $\left(\mathbf{g ~ m}^{-2}\right)$} \\
\cline { 2 - 7 } & 4WAT & 8WAT & 12WAT & 4WAT & 8WAT & 12WAT \\
\hline Topstar $\left(\mathrm{ml} \mathrm{ha}^{-1}\right)$ & & & & & & \\
400 & 1.67 & $2.33 \mathrm{~b}$ & $2.33 \mathrm{~b}$ & $7.27 \mathrm{~b}$ & $15.07 \mathrm{~b}$ & $28.47 \mathrm{~b}$ \\
600 & 1.33 & $1.00 \mathrm{c}$ & $1.67 \mathrm{c}$ & $3.07 \mathrm{c}$ & $8.93 \mathrm{~d}$ & $14.60 \mathrm{c}$ \\
& & & & & & \\
Cranstan $\left(\mathrm{ml} \mathrm{ha}^{-1}\right)$ & & & & & & \\
800 & 2.00 & $2.95 \mathrm{~b}$ & $2.67 \mathrm{~b}$ & $6.23 \mathrm{~b}$ & $17.07 \mathrm{~b}$ & $32.37 \mathrm{~b}$ \\
1250 & 2.67 & $2.00 \mathrm{c}$ & $2.67 \mathrm{~b}$ & $6.70 \mathrm{~b}$ & $12.73 \mathrm{c}$ & $22.67 \mathrm{~b}$ \\
Hoe weeding & 1.00 & $2.00 \mathrm{c}$ & $1.67 \mathrm{c}$ & $3.07 \mathrm{c}$ & $13.87 \mathrm{c}$ & $17.23 \mathrm{~b}$ \\
Weedy check & 3.45 & $4.00 \mathrm{a}$ & $5.67 \mathrm{a}$ & $15.87 \mathrm{a}$ & $20.07 \mathrm{a}$ & $67.60 \mathrm{a}$ \\
LSD $_{0.05}$ & 0.87 & 1.04 & 1.00 & 2.56 & 3.07 & 8.15 \\
\hline
\end{tabular}

Means followed by the same letter (s) within a column in each treatment are not significantly different at $5 \%$ using LSD * Significant at $5 \%, \mathrm{NS}=$ not significant. $\mathrm{ml} \mathrm{ha}^{-1}=$ milligram per hectare, WAT $=$ weeks after Transplanting.

$\mathrm{ml} /$ ha produced a greater number of grains per panicle that was comparable to plots weeded twice at 3 and 6 WAT and the weedy check plots recorded the least value for number of grains per panicle. Higher value for 1000 grain weight was recorded in the Topstar treated $\left(600 \mathrm{ml} \mathrm{ha}^{-1}\right)$ than the other weed control treatments and the weedy check had the least. Likewise, a similar trend was observed in the grain yield per hectare.

\section{DISCUSSION}

Topstar at higher rate of $600 \mathrm{ml} \mathrm{ha}^{-1}$ effectively control weeds by inhibiting cell division and elongation of weed seed beyond the critical period of rice growth. This minimized competition for growth resources between the crops and the weeds particularly during the critical period of weed interference, leading to greater efficiency in utilizing growth and yield resources by the crop. This also led to vigorous crop growth and development of larger vegetative parts and consequently achieving a high light interception for increased dry matter production and yield. This result is in line with findings of Ajala et al. (2018) who reported significant decrease in weed infestation when treated with herbicide on rice. However, weedy check had 
Table 3. Effect of Weed control treatment on panicle length, number of grain per panicle, 1000 grain weight and grain yield of Rice at Birnin Kebbi during 2019 wet season.

\begin{tabular}{lcccc}
\hline Weed control & $\begin{array}{c}\text { Panicle } \\
\text { length }(\mathbf{c m})\end{array}$ & $\begin{array}{c}\text { Grain number } \\
\text { per panicle }\end{array}$ & $\begin{array}{c}\mathbf{1 0 0 0} \text {-grain } \\
\text { weight } \mathbf{( g})\end{array}$ & Yield $\left(\mathbf{t ~ h a}^{-1}\right)$ \\
\hline Topstar $\left(\mathrm{ml} \mathrm{ha}^{-1}\right)$ & & & & \\
400 & $21.27 \mathrm{a}$ & $74.33 \mathrm{~b}$ & $18.97 \mathrm{c}$ & $2.59 \mathrm{c}$ \\
600 & $25.27 \mathrm{a}$ & $123.00 \mathrm{a}$ & $28.33 \mathrm{a}$ & $3.49 \mathrm{a}$ \\
& & & & \\
Cranstan $\left(\mathrm{ml} \mathrm{ha}^{-1}\right)$ & & & & \\
800 & $23.21 \mathrm{a}$ & $82.67 \mathrm{~b}$ & $19.33 \mathrm{c}$ & $2.42 \mathrm{c}$ \\
1250 & $25.59 \mathrm{a}$ & $107.00 \mathrm{~b}$ & $24.67 \mathrm{~b}$ & $3.07 \mathrm{~b}$ \\
Hoe weeding 4 \& 8 WAT & $26.40 \mathrm{a}$ & $120.00 \mathrm{a}$ & $26.33 \mathrm{~b}$ & $3.05 \mathrm{~b}$ \\
Weedy check & $12.77 \mathrm{~b}$ & $47.67 \mathrm{c}$ & $11.67 \mathrm{~d}$ & $0.23 \mathrm{~d}$ \\
LSD 0.05 & 3.20 & 17.34 & 2.65 & 0.45 \\
\hline
\end{tabular}

Means followed by the same letter (s) within a column in each treatment are not significantly different at $5 \%$ using LSD

${ }^{*}=$ Significant at $5 \%, \mathrm{NS}=$ not significant. $\mathrm{ml} \mathrm{ha}^{-1}=$ milligram per hectare, WAT = weeks after Transplanting.

significantly higher weed cover and weed dry weight than the 2-hoe weeded control and application of Topstar and Cranstan at all rates, this could be attributed to intense competition for scarce resources between weeds and crop plants. This result is in accordance with the finding of $\mathrm{Na}$ Allah et al. (2017) who reported that weedy check treatments had significantly higher weed cover score and weed dry weight than application of herbicide and hoe weeding on cowpea.

The positive response of most of the yield component and grain yield such as panicle length, panicle weight, 100grain weight and grain yield to weed control treatments could also be attributed to effective weed control management and the ability for weed control measure applied which control weeds beyond the level that can have a harmful effect on the performance of rice crop. This result is in line with the findings of Ajala et al. (2018) who reported increased in yield and yield attributes of rice due to application of herbicide to weed in rice field.

\section{Conclusions}

Based on the findings of this research it could be concluded that application Topstar at $600 \mathrm{ml} \mathrm{ha}^{-1}$ gave the best result in weed management and highest value in growth and yield components.

\section{Recommendation}

Topstar at $600 \mathrm{ml} \mathrm{ha}^{-1}$ is recommended for rice production in the study area.

\section{CONFLICT OF INTEREST}

The authors declare that they have no conflict of interest.

\section{REFERENCES}

Abiwon, B. O., Dambaba, N., \& Salihu, B. Z. (2016). Genetic improvement of rice in Nigeria for enhanced yield and grain quality - A review. Asian Research Journal of Agriculture,1(3), 1-18.

Anonymous (2009). FAO bulletin of statistics. Food and Agriculture Organization of the United Nations.

Ajala, A., Muhammad. A., \& Yakubu, A. I. (2019). Correlation study on growth and yield component of rice (Oryza sativa L.) varieties grown under integrated weed management in Sudan savanna of Nigeria. Journey of Agriculture and Ecology Research International, 19(1), 1-6.

Balasubramanian, V., Sie, M., Hijmans, R. J., \& Otsuka, K. (2007). Increasing rice production in sub-Saharan Africa: challenges and opportunities. Advances in Agronomy, 94, 55133.

Black, C. A. (1965). Methods of soil analysis II chemical and microbiological properties. American Society of Agronomy, Madison Wisconsin: 1572

Food and Agriculture Organization (FAO) (2017). The state of food and agriculture. Food and Agriculture Organization of United Nation, Rome, 2017.

Na-Allah, M. S., Mukhtar, A. A., Mahadi, M. A., Tanimu, M. U., \& Muhammad, A. (2017). Performance of cowpea (Vigna unguiculata (L) Walp) under irrigation as influenced by weed management methods and intra row spacing. Journal of Agricultural Science and Practice, 2(4), 58-65.

Nigeria National News (2012). Weather report. A news report by Nigeria National News. Retrieved from https://nnn.ng/

Rodenburg, J., \& Johnson, D. E. (2009). Weed management in rice-based cropping systems in Africa. Advances in Agronomy, 103, 149-218. 